\title{
Distributed Creativity: Language Learning and the Craft Approach to Creativity
}

\section{Cameron Smith \\ Aichi Gakuin University}

\section{Reference Data}

Smith, C. A. (2021). Distributed creativity: Language learning and the craft approach to creativity. In P. Clements, R. Derrah, \& P. Ferguson (Eds.), Communities of teachers \& learners. JALT. https:// doi.org/10.37546/JALTPCP2020-02

This paper examines shortcomings in the individualist model of creativity and the implications that has for understanding creativity in second language education. The author first examines why education policies in Japan and around the world currently promote creativity and presents what until now has been the standard approach to understanding creativity. It discusses whether this approach, highly centred on the creative individual, is appropriate for foreign language education and education in general. It then introduces the concept of "participatory" or "distributed" creativity, in particular from the work of Vlad Petre Glăveanu, as offering a possible solution to problems with the individual sociocognitive model. Finally, the author argues that, by bringing in collaboration, increased audience awareness, and "openness to difference" in a "craft" approach to creativity, the distributed model supports genre approaches in teaching and the promotion of collaborative social skills in students in order to boost their ability to contribute creatively.

本稿は、創造性の個人主義的モデルの短所と、それが第二外国語教育における創造性の理解に関して示唆する点を考察 する。まず、日本および世界の教育政策で、なぜ創造性が推奨されているのかについて、これまでの一般的なアプローチを提

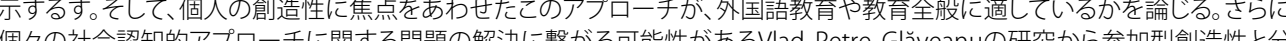
個々の社会認知的アプーチに関する問題の解決に繋がる可能性があるVlad Petre Glăveanuの研究から参加型創造性之分 散型創造性の概念につて紹介する。最後に、創造性へのクラフト・アプローチにおいて、コラボレーションオーデイエンスの

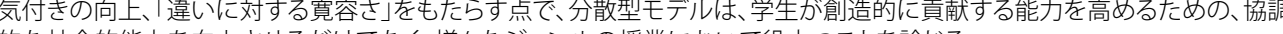
的な社会的能力を向上させるだけでなく、様々なジャンルの授業において役立つことを論じる。 he current age is pervaded, according to Reckwitz (2017), by the "creativity dispositif." That is, we live in a period where creativity-typically defined as the production of new and valuable things-dominates how we think people should be. We have moved from considering the creative individual as an outsider and abnormal genius to treating creativity as a fundamental aspect of being human. Not only are creative industries (media, design, gaming, advertising, etc.) increasingly prominent economically (UNCTAD, 2019), but consumers of creative products are themselves expected to respond in a creative manner, such as in content provision (blogging, YouTube channels, etc.) and reaction to content (fan fiction, audience participation). At the same time, a rapidly changing technological environment, characterized by automation and computerization of essentially non-creative tasks formerly done by people, as well as accelerated demand for innovation, has led to the increased value of creativity and adaptability in the labour market (Grobman \& Ramsey, 2020), and therefore, to the promotion of creativity in education too.

In this paper I examine how creativity has typically been viewed and argue that recent developments in creativity research critiquing traditional approaches have particular relevance to foreign language educators. Based on the concept of "distributed creativity" pioneered by Vlad Petre Glăveanu, I argue for teachers to use his "craft" approach to creativity to better help students as language learners and as future members of the workforce.

\section{Creativity in Education Policy}

The push to promote creativity in education is evident around the world. The Organization for Economic Co-operation and Development (OECD) identified creativity as a key competency (2003), the United Nations Development Program (UNDP) and UNESCO (2013) view it as crucial to sustainable development, and the European Union (2011) sees it as vital for cultural diversity and inclusive economic growth. Creativity 
features in curriculum policies throughout EU countries (Heilmann \& Korte, 2010) while the work of the US-based Partnership for 21st Century Skills has been integrated into education systems in North America and Asia-Pacific (Trilling \& Fadel, 2009).

Japan is part of this global conversation. Creativity is now a basic goal of education (MEXT, 2013). The so-called 21st century skills are promoted through the concept of "zest for life" (ikiru chikara) (Kimura \& Tatsuno, 2017), a concept which Smith (2018) argued aligns with common models of the creative process found in the literature on creativity. In addition to the perceived need for innovation and more humanized education compared to the regimented model of the post-war era, Japanese education policy documents also now focus on social renewal and the need to create "new values" (MEXT, 2013), a change prompted partly by a nationalist political revival and partly by the economic shock of 2008 and the disasters of 2011 that intensified a sense that the former economic powerhouse was stagnating economically, demographically, and educationally (Smith, 2018). Figure 1 (from MEXT 2012) shows the three "key concepts" included in the Education Ministry's 2013 Second Basic Plan. One should note in particular how creativity is related to independence and collaboration, and the goal of a lifelong-learning society.

Figure 1

Key Concepts that "Identify the Future Direction of Society" (from MEXT 2012)

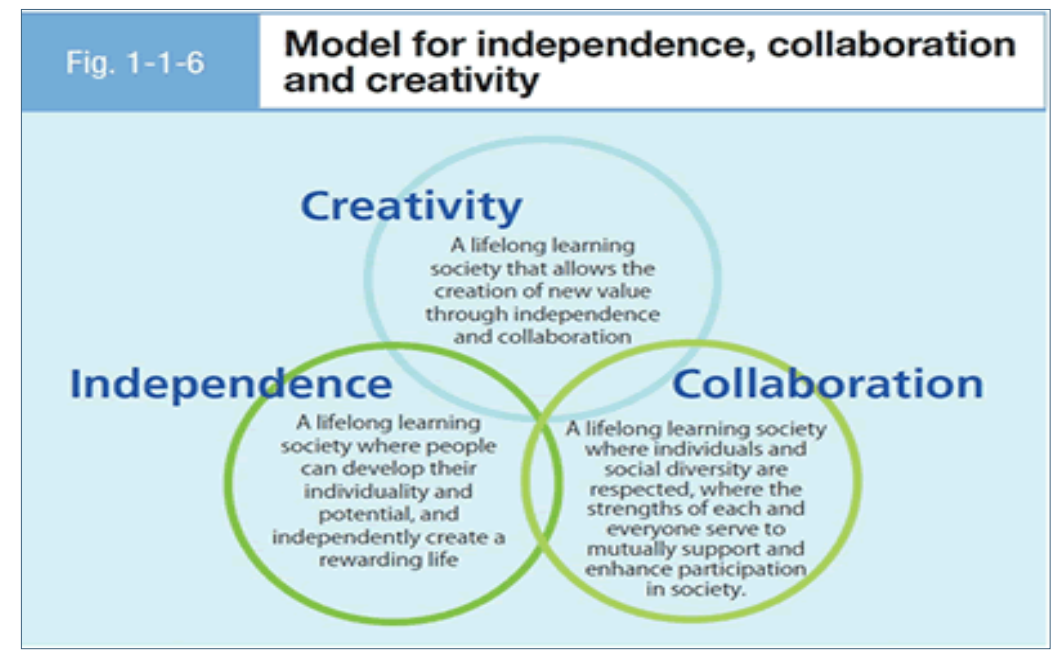

Although long neglected in foreign language education, there is now increasing interest in creativity in EFL too, with several books written or edited by major scholars. For example, contributions in Swann et al. (2011) considered the importance of creativity in language production and language play. Jones and Richards (2015) gave authors free rein to explore the role of creativity both in thinking about foreign language teaching and in practice in the classroom. Li (2019) assembled case studies that consider the connections between language learning, bilingualism, creativity and critical thinking, while Maley and Kiss (2017) brought the now substantial body of research literature on creativity to bear on promoting teacher and student creativity in the classroom.

The rationale for investigating creativity in language teaching is based on five distinct propositions:

1. Language production is a creative act, and thus promoting student creativity is necessary for them fully use their new language. This proposition refers to language production in general, as well as more specifically the often-neglected role (but championed by Ronald Carter (2004) and others) of playfulness in everyday language use.

2. Learning is a creative process (Beghetto, 2016), as students develop new and valuable understandings, identify problems, and resolve them.

3. Teaching is, or is better as, a creative act: "Teaching with creativity" (Beghetto, 2019).

4. Teachers should promote critical and creative thinking in their students as a broader educational, economic, and societal goal.

5. Creative tasks are themselves motivating activities that allow students to develop themselves (Bramwell et al., 2011).

Although it is sometimes tempting to treat creativity as indefinable or beyond analysis (e.g., Radclyffe-Thomas, 2015), as mentioned above, there is a developed field of creativity research that seeks to define and understand what creativity is and what may encourage it. In the following section, I shall set out some standard approaches to these questions. After that, I will introduce critiques of the individualist focus inherent in some of these approaches in order to show the significance and relevance of Glăveanu's model of distributed creativity to language educators, and how viewing language learning as a "craft" can be applied in practice in the classroom. 


\section{A Brief Outline of Standard Creativity Models}

J.P. Guilford's 1950 American Psychological Association Presidential address calling for more research into creativity is commonly taken as the modern beginning of a now flourishing research field (Plucker, 2001). Here, I outline four prominent frameworks from the literature. Two describe what creativity is, and two how creativity comes about.

The first framework defines creativity along two dimensions as "the production of novel, useful products" or various synonymous formulations thereof (Mumford, 2003, p. 110), with what counts as (a) novel and (b) useful varying according to the context. In terms of language use, creativity may be seen in utterances never said before that have a useful or valuable effect, whether that is literary or practical (Plucker et al., 2004). This framework also helps to understand cultural differences in conceptions of creativity, with western cultures tending to emphasise originality more, while east Asian cultures tending to emphasise value and social usefulness (Smith 2016).

Second is the "four Cs" classification of what is novel (Kaufman \& Beghetto, 2009). Big-C refers to the "eminent" creativity of famous artists, scientists and so on; pro-C refers to everyday professional creativity, such as a chef creating an entrée that is new but not groundbreaking; little-C refers to creativity in everyday life that is new to the creator but not necessarily to the world, such as arranging photos beautifully in an album; and mini- $\mathrm{C}$ is insight and the construction of knowledge inherent in learning. Thus, when a student learns to innovate in a language at a level that might be banal for a native speaker, this can still be considered novel as "mini-" and then "little-C" creativity.

The third framework is the "four Ps" model originated by Rhodes (1961) which considers:

- Person (what kind of individual is creative);

- Process (the cognitive processes followed by the creative individual);

- Press, sometimes called Place (the environment the individual is in); and

- Product (what items are considered creative).

For educators, this analysis is potentially useful in structuring how to manage and better incentivise (or avoid disincentivising) creative behaviour from students (Cropley, 2006).

The last framework is the two-stage model of creative cognition: divergent thinking (ideation, brainstorming, etc.) and convergent thinking (idea selection, solution identification). Guilford's 1950 speech entreated researchers to understand the value of both (Cropley, 2006). However, as Cropley observed, divergent thinking has come to dominate many people's conception of creativity. For example, the most commonly used tests of creativity largely focus on idea generation and fluency, encouraging a view of creativity as "coming up with wild ideas" (Baer, 2011, p. 312). It is not uncommon for educators to stress "thinking outside the box" as JALT named its 2010 conference.

In the latter two models that seek to explain how creativity occurs, creativity is taken to be within the individual, as if it were a general cognitive skill. This individualistic focus particularly reflects Western views of creativity and creative genius since the Renaissance. As such it tends to dominate the views of western-origin educators teaching in Japan (Smith, 2016). However, this perspective may distract us from fully exploiting creativity to improve language learning outcomes.

\section{Problems with the Individual Model}

Are Creative Individuals Better Language Learners?

Although one might assume that creative people make better language learners, the evidence is very mixed. Research typically assesses general creative cognitive skills or behaviours of students and compares them to their progress in language learning in a variety of ways. While Otto (1998) found many significant positive relationships between creative ability and language test scores, Albert and Kormos (2004) found a more complicated picture, and only a weak series of relationships. Smith (2017), replicating an earlier exploratory study, found no relationship between reported creative behaviour and output (word count) in student spoken narrative. There is, as yet, no well-argued, empirically supported model of how creative cognition interacts with foreign language learning. A major obstacle to such a model may be that creativity has a strong domainspecific component: the ability of an individual to be significantly creative in any one area depends greatly on their knowledge or expertise in the area such that even general creativity training does not appear to improve creativity in a domain (Baer, 2016). It may be that the characteristics identified in general assessments of creative ability are not ones that help with language learning.

Does the Individual Model Contradict the Goal of Collaborative Learning?

Having students working together in groups through cooperative and collaborative learning has long been promoted in foreign language education (Oxford, 1997). Research has shown that students working together improves learning outcomes both narrowly in terms of subject achievement and broadly for students as people (McGafferty et al., 
2006). However, creativity research has what appears to be an unpleasant message that "group creativity research started by comparing individual and group creativity and from these comparisons one conclusion came out repeatedly: groups are bad for creativity" (Glăveanu, 2011, p. 478). Groups have been found to produce fewer, less original, lower quality ideas for a number of reasons: "production blocking" (ideas interfering with one another); social anxiety inhibiting people from revealing less conformist ideas; "downward norm-setting" where the group tends to perform at the level of its weakest member; free-riding on the work of the group and so on (Glăveanu, 2011, p. 478). These problems can be ameliorated in a number of ways. For example, a teacher can assign individual students roles within the creative process as if they were components inside the head of a creatively-engaged individual: someone to describe the problem, someone to retrieve knowledge about the problem, someone to generate solutions and so on. Alternatively, teachers can seek diversity in group membership to promote diversity in perspective and knowledge. However, the former solution of giving roles is somewhat cumbersome and only appropriate to activities where the goal is a little-C approach to doing complex tasks in the target language rather than mini-C creativity of insight and knowledge construction involved in language acquisition. The latter solution of maximising diversity of each group also may prove challenging when teaching students of the same age, cultural background, and L1.

Is the Individual Model of Creativity Equitable?

Clapp (2017) identified eight "crises" of creativity stemming from the individualist focus that he argued hinder fairness and access in the classroom. Five of the eight are relevant to our current discussion.

1. The misconception that "some kids are more creative than others."

2. The "I'm just not a creative person" syndrome where people internalise the idea they are uncreative and so fail to develop a growth mindset.

5. The inadequate preparation of young people for success in life and work by promoting the idea of the lone genius rather than the socially engaged member of a diverse team.

6. The assumption that creativity is socially and culturally neutral.

7. The misalignment of identity in the representation of collective icons.

These crises are pertinent to EFL education in Japan. Firstly, the western association of creativity with extraversion, disruption, and non-conformity contrasts with Eastern views of creativity as defined by benefit to society, and might tempt western-origin educators to dismiss Japanese students as less creative (Smith, 2016). Secondly, regular survey results suggest that for a long time, Japanese people have had a strikingly low perception of themselves as "creative" (Nakamura et al., 2015). This low self-efficacy exists even as Japanese students do well on international PISA tests of creative problem solving (OECD, 2014) and Japanese science and culture exert much soft power globally (Heng, 2010). As a result, teachers should not assume the individualist model is neutral. It might be culturally biased against Japanese students. Thirdly, regarding crisis (7), models of individual genius that teachers often promote (e.g., Einstein, Beethoven, and other white, European-heritage figures) are not only problematic for the creative self-efficacy of non-white students in American classrooms (Clapp 2017): for Japanese students, they represent a different set of cultures that consciously, aesthetically, promote themselves as creative, potentially exacerbating self-perceptions of Japan as a less creative society. Finally, while some Japanese students might respond well to being asked to perform in accordance with the western individual creative model, crisis (5) suggests that emulating the disruptive creative genius is not necessarily good preparation for the world of work, particularly in Japan. One can go further, as Kalin (2018) did, and suggest that in the artistic model of creativity, "artists - with their drive to innovate, flexible production practices, and tolerance for precarity - are being held up as ideal workers" (2018, p. 13). That is, the model prepares students for exploitation by employers in the post-industrial age just as Ken Robinson had argued education was designed to produce people ideal for exploitation in the industrial age (Robinson, 2006). Therefore, teachers need move away from a model that views the individual as the locus of creativity, and towards one which is more appropriate for language learning, which allows for collaboration as a boost to creativity rather than a hindrance, and which also suits the broader demand for creativity in educating students for the future.

\section{The Biography of the Idea and the Sociality of Creativity}

Clapp (2017) proposed shifting focus from the inventor to the thing invented: the biography of the idea. Clapp argued that creativity should be seen as "socially rearranged and literally redistributed: individuals enact their agency through the creative idea development process, but no one individual or group has ownership over any one creative idea...i.e., creativity is something one participates in, along with others" (2017, p. 92). By looking at the history of a creative idea, one can understand how individuals interact to improve it. Clapp cited the theory of relativity: even an idea heavily associated with one individual can become a history of how Einstein's idea was influenced by the work of 
others. Clapp's move sheds better light on how the creative process is a social phenomenon. His case studies of students working towards the Boston ArtScience Prize illustrate how they can fruitfully work together in the development of ideas (Clapp, 2017).

Clapp's (2017) motivation was more equity and access in creative activities in school. On the other hand, Glăveanu's $(2013 ; 2014)$ model of distributed creativity comes directly from a critique of the sociocognitive approach-typified by the componential "Four Ps" framework of person, press/place, product and process-that underpins the individual model. Glăveanu instead framed creativity as situated in the world:

it can no longer be said to reside 'within' the person, the product etc. It emerges as a form of action engaged in by various actors...in relation to multiple audiences... exploiting the affordances of the cultural world (symbolic and material) and leading to the generation of artefacts (appreciated as new or useful by self and/or others). (2013: 27, emphasis added).

The "Five As" model differs from the four Ps model in that each of the As is relationally defined. Actors act for and with audiences using the material and cultural resources (affordances) available to produce the creative product (artefact). Thus, creativity is recast as a social phenomenon arising from these interactions. To illustrate this model, Glăveanu (2014) cited Romanian egg painting: the more experienced painters coach the less experienced over time in the production of artistically decorated eggs for both Romanian and foreign audiences (who prefer more traditional and more multicoloured designs respectively), learning to work with how the paint and wax behave, constantly remaking and innovating within the culture.

Before addressing this model's practical benefits, it is worth reviewing how it helps our understanding of creativity more generally. In the thinking outside the box model of individual creativity, knowledge appears almost as a constraint, making domain specificity - how formal knowledge and training in an area assist creativity-feel paradoxical. However, in the distributed model, domain knowledge becomes a shared representational space between creative actors: it supports creative improvements. This representational space is enhanced by sharing unique experiences. Groups can thus be creative if we focus on building trust and sharing diverse perspectives and knowledge rather than rely on short-term synergy. The distributed model also incorporates the audience. In the real world, people typically create with an audience already in mind rather than in a vacuum (Glăveanu, 2013). None of this displaces what we know about fostering creativity in individuals: playfulness, openness to experience, intrinsic motivation, clear goal setting, and so on still encourage creativity (e.g., Amabile, 1998).
However, that should be understood as one aspect of a process of interaction with other people and real-world objects.

\section{Creativity of Craft, Language Learning, and the Role of Genre and Difference}

Through his sociocultural view, Glăveanu (2018) identified a key bias in common conceptions of creativity: we mostly model it as the creativity of "successful" people, in the first place, artists, and then secondarily inventors: champions of divergent and convergent thinking. According to Glăveanu (2018), we ignore the creativity of "craft", that is:

the range of activities... that both continue and renew cultural traditions and social practices. Craft requires skill, practice, and leads to mastery. Creativity as a mark of masterful activity transcends (by integrating) existing dichotomies ... between originality and value, divergence and convergence, science and art. Most of all, it challenges the separation between self and other since no craft was ever invented or performed by solitary individuals. (p. 29)

This craft approach to creativity, as a social activity in a community requiring skills and practices to be mastered, shaped by established practices while at the same time accommodating renewal and innovation, looks very much like learning a language. Perhaps unsurprisingly, Glăveanu cited Vygotsky's zone of proximal development to understand how "collaboration with others and the resources of a shared culture" scaffold creativity (2018, p. 30). It also captures how diversity helps creativity in communities: novel contributions to the shared representational space emerge from diverse backgrounds.

In terms of language learning, action is the act of formulating spoken or written texts, whether in speech or writing; the actors (learners and teachers) draw upon their linguistic and cultural knowledge (affordances) to produce and interact with those texts (artefacts) shaped in reference to their audiences (communication partners, readers, international colleagues etc.). The teacher becomes the master craftsperson training the apprentice; the students become resources for each other. Success in creatively using language and in the creative acquisition of language depends on more than a spark from within an extrovert or nonconformist individual.

Moreover, the craft approach has many similarities with the "genre approach" associated with teaching EFL writing. According to Hyland (2008), "genre," denoting groups of texts that have similar purposes, 
is based on the idea that members of a community usually have little difficulty in recognising similarities in the texts they use frequently and are able to draw on their repeated experiences with such texts to read, understand and perhaps write them relatively easily. (p. 543)

As Lee (2013) noted, the genre approach is often accused of "repressing" creativity by limiting student choice. However, if one re-casts genre as a resource - an affordance which enables students not only to produce more valuable work but also to communicate with each other in a shared space of understandings, and to provide structure to problem solving (just as the eggpainters must react to the behaviour of wax and paint), it can become a fertile vehicle for creativity. Such an approach has borne fruit in EFL creative writing (Holmes \& Moulton, 2001); it is not unreasonable to see it doing so in genre-based approaches more generally, not only in writing, but also in communicative speaking contexts as well.

A key concept in the craft approach is difference as both the "fruit" and the "roots" of creativity (Glăveanu \& Beghetto, 2017). Difference is "fruit" in that creativity is the generation of difference between what was and what is: new, added value. When craftspeople make new objects based on previous practices, they build upon what is already there. Difference is also the "root" of creativity because creativity can arise from exploitation of difference-between what is and what should be, between people's resources and perspectives (in a class: between students, and students and teachers), between the possible and impossible (fantastical), and so on-to generate valuable novelty. Therefore, openness to the difference of others, and the ability to take the perspective of others, supports creativity.

\section{Implications for Language Educators}

Viewing prescriptions of form or genre as inimical to creativity is an example of the "thinking outside the box" perspective. As I have argued, this approach fails to model creative processes in language learning helpfully and fairly, and puts undue pressure on students to perform according to teacher conceptions of the creative individual. By overemphasising divergent thinking rather than the implementation and development of ideas, it also does not prepare students to be creative in the workplace, where longerterm collaboration with a community of colleagues - where creativity is distributed between people - is more normal than the model of the unfettered artist or inventor. If one revisits Figure 1, one can see that this craft approach to creativity, based on participation, collaboration, and the importance of diversity, also better meets societal goals.
In challenging how we think about creativity, the craft approach, with its similarity to genre approaches, paradoxically legitimises teaching practices that many have been engaging in all along. For teachers wishing to promote language learner creativity, knowledge of and teaching of genre and discourse patterns become more important. Sharing the practices of a community in specific contexts becomes relatively more empowering than generalised techniques of creative cognition. For example, more convention-bound situations, such as a contract negotiation, or a visit to a doctor, modelled with ostensibly limiting dialogues, can instead be opportunities for students and teachers to explore and exploit difference to produce the kind of creativity that aids and motivates language learning. Accordingly, student confidence and competence in sharing, helping, and gaining awareness of others' needs-openness to difference-may help them as language learners, genre provides a platform for that.

However, certain practices may be less conducive to creativity. For example, an individualist model might place peers as evaluators outside of the creative process Teachers may employ teacher-defined checklists common in peer-interaction in writing lessons to evaluate individual students' work, an approach which many believe undermines autonomy (e.g., Chang, 2016) and thus creativity. Glăveanu and Beghetto (2017) warned generally against "monocular" approaches which, even when appearing democratic, push students towards alignment with the teacher's perspective (for example, brainstorming to arrive at an answer the teacher had already decided), eliminate difference, and echoing Clapp's “crises," privilege students who share the teacher's background. Conversely, teachers wishing to relinquish such control, bu still deploying the individualist lens, might present students more or less with a blank piece of paper and an injunction to "be creative." This approach offers little by way of difference (between self and others, between "actor" and "affordance", between creator and audience) to exploit.

By contrast, a distributed creativity craft approach stresses the role of studentpeers and teachers as audience-aware co-creators, working within a genre looking for opportunities to be creative. We have long known that creativity is better managed by having clarity in goals, but flexibility in how to achieve them (Amabile, 1998). Distributed creativity and the craft approach might help educators better understand why.

\section{Bio Data}

Cameron Smith is a lecturer at Aichi Gakuin University. He taught English in Russia before completing his PhD in Russian health reform at Edinburgh University. He began 
teaching in Japan in 2002. His main research interests are the relationship between creativity and language learning, creative writing in $\mathrm{L} 2$, and content and language integrated learning (CLIL).<casmith@dpc.agu.ac.jp>

\section{References}

Albert, A., \& Kormos, J. (2004). Creativity and narrative task performance : An exploratory study. Language Learning, 54(2), 277-310. http://dx.doi.org/10.1111/j.1467-9922.2004.00256.x

Amabile, T. M. (1998). How to kill creativity. Harvard Business Review, September-October, 77-87. Baer, J. (2011). How divergent thinking tests mislead us: Are the torrance tests still relevant in the 21 st century the division 10 debate. Psychology of Aesthetics, Creativity, and the Arts, 5(4), 309313. https://doi.org/10.1037/a0025210

Baer, J. (2016). Domain specificity of creativity. Academic Press. https://doi.org/10.1016/B978-0-12 799962-3.00005-7

Beghetto, R. A. (2016). Creative learning: A fresh look. Journal of Cognitive Education and Psychology, 15(1). https://doi.org/10.1891/1945-8959.15.1.1

Beghetto, R. A. (2019). Creativity in classrooms. In J. C. Kaufman \& R. J. Sternberg (Eds.), The Cambridge handbook of creativity (2nd ed., pp. 587-606). Cambridge University Press. https://doi. org/10.1017/9781316979839.029

Bramwell, G., Reilly, R., Lilly, F., Kronish, N., \& Chennabathni, R. (2011). Creative teachers. Roeper Review, 33(4), 228-238. http://dx.doi.org/10.1080/02783193.2011.603111

Carter, R. (2004). Language and creativity. Routledge. https://doi.org/10.4324/9780203468401

Chang, C. Y. (2016). Two decades of research in L2 peer review. Journal of Writing Research, 8(1), p. 81-117. http://dx.doi.org/10.17239/jowr-2016.08.01.03

Clapp, E. P. (2017). Participatory creativity: Introducing access and equity in the creative classroom. Routledge. http://dx.doi.org/10.4324/9781315671512

Cropley, A. (2006). In praise of convergent thinking. Creativity Research Journal, 18(3), 391-404. https://doi.org/10.1207/s15326934crj1803_13

European Union. (2011). Official Journal. Official Journal of the European Union, 54.

Glăveanu, V. P. (2011). How are we creative together? Comparing sociocognitive and sociocultural answers. Theory \& Psychology, 21(4), 473-492. https://doi.org/10.1177/0959354310372152

Glăveanu, V. P. (2013). Rewriting the language of creativity: The five A's framework. Review of General Psychology, 17(1), 69-81. https://doi.org/10.1037/a0029528

Glăveanu, V. P. (2014). Distributed creativity: Thinking outside the box of the creative individual. Springer International Publishing. https://doi.org/10.1007/978-3-319-05434-6
Glăveanu, V. P. (2018). Educating which creativity? Thinking Skills and Creativity, 27, 25-32. https:// doi.org/10.1016/j.tsc.2017.11.006

Glăveanu, V. P., \& Beghetto, R. A. (2017). The difference that makes a "creative difference" in education. In R. A. Beghetto \& B. Sriraman (Eds.), Creative contradictions in education: Cross diciplinary paradoxes and perspectives (pp. 37-54). Springer. http://dx.doi.org/10.1007/978-3-31921924-0_3

Grobman, L., \& Ramsey, E. M. (2020). Major decisions. University of Pennsylvania Press. https://doi. org/10.9783/9780812296945-014

Heilmann, G., \& Korte, W. B. (2010). The role of creativity and innovation in school curricula in the EU27: A content analysis of curricula documents. European Commission Joint Research Centre Institute for Prospective Technological Studies. Retrieved from http://www.pim.com.mt/pubs/ JRC_curricula.pdf

Heng, Y. K. (2010). Mirror, mirror on the wall, who is the softest of them all? Evaluating Japanese and Chinese strategies in the 'soft'power competition era. International Relations of the AsiaPacific, 10(2), 275-304. https://doi.org/10.1093/irap/lcp023

Holmes, Vicki. L., \& Moulton, M. R. (2001). Writing simple poems: Pattern poetry for language acquisition. Cambridge University Press.

Hyland, K. (2008). Genre and academic writing in the disciplines. Language Teaching, 41(4), 543-562. https://doi.org/10.1017/S0261444808005235

Jones, R. H., \& Richards, J. C. (2015). Creativity and language teaching. In R. H. Jones \& J. C. Richards (Eds.), Creativity in language teaching: perspectives from research and practice. Routledge. http://dx.doi.org/10.4324/9781315730936-1

Kalin, N. M. (2018). The neoliberalization of creativity education. Palgrave Macmillan. https://doi. org/10.1007/978-3-319-71525-4

Kaufman, J. C., \& Beghetto, R. A. (2009). Beyond big and little: The four C model of creativity. Review of General Psychology, 13(1), 1-12. https://doi.org/10.1037/a0013688

Kimura, D., \& Tatsuno, M. (2017). Advancing 21st century competencies in Japan. Asia Society Center for Global Education.

Lee, N.-K. (2013). The genre-based writing instruction in EFL. Language Research, 49(2), 311-332.

Li, L. (2019) (Ed.). Thinking skills and creativity in second language education: Case studies from international perspectives. Routledge. http://dx.doi.org/10.4324/9781315098920

Maley, A., \& Kiss, T. (2017). Creativity and English language teaching: from inspiration to implentation. Springer International Publishing. http://dx.doi.org/10.1057/978-1-137-46729-4

McGafferty, S. G., Jacobs, G. M., \& da Silva Iddings, A. C. (Eds.). (2006). Cooperative learning and second language teaching. Cambridge University Press. 
MEXT. (2012). Education white paper 2012 Section 1 Special feature. https://warp.da.ndl.go.jp/ info:ndljp/pid/11402417/www.mext.go.jp/b_menu/hakusho/html/hpab201201/detail/1344908. htm

MEXT. (2013). The second basic plan for the promotion of education. Ministry of Education, Culture, Sports, Science and Technology. http://www.mext.go.jp/en/policy/education/lawandplan/ title01/detail01/1373796.htm

Mumford, M. D. (2003). Where have we been, where are we going? Taking stock in creativity research. Creativity Research Journal, 15(2-3), 107-120. https://doi.org/10.1080/10400419.2003. 9651403

Nakamura, T., Tsuchiya, T., \& Maeda, T. (2015). 国民性の研究第 13 次全国調查 [A study of the Japanese national character: The thirteenth nationwide survey]. 統計数理研究所研究リポート [ISM Survey Research Report] 116.

OECD. (2003). Selection of key competencies for a successful life - Executive Summary.

OECD. (2014). PISA 2012 results: Creative problem solving: Students' skills in tackling real-life problems (Volume V). https://doi.org/10.1787/9789264208070-en

Otto, I. (1998). The relationship between individual differences in learner creativity and language learning success. TESOL Quarterly, 32(4), 763-773. http://dx.doi.org/10.2307/3588011

Oxford, R. L. (1997). Cooperative learning, collaborative learning, and interaction: Three communicative strands in the language classroom. The Modern Language Journal, 81(4), 443-456. https://doi.org/10.1111/j.1540-4781.1997.tb05510.x

Plucker, J. A. (2001). Introduction to the special issue: Commemorating Guilford's 1950 Presidential Address. Creativity Research Journal, $13(3$ \& 4), 247. https://doi.org/10.1207/ S15326934CRJ1334_02

Plucker, J. A., Beghetto, R. A., \& Dow, G. T. (2004). Why isn't creativity more important to educational psychologists? Potentials, pitfalls, and future directions in creativity research. Educational Psychologist, 39(2), 83-96. https://doi.org/10.1207/s15326985ep3902

Radclyffe-Thomas, N. (2015) Fashioning cross-cultural creativity: Investigating the situated pedagogy of creativity. Psychology of Aesthetics, Creativity and the Arts, 9(2). pp. 152-160

Reckwitz, A. (2017). The invention of creativity. Polity Press.

Rhodes, M. (1961). An analysis of creativity. Phi Delta Kappan, 42(7), 305-310.

Robinson, K. (2006, February). Do schools kill creativity [Video]. TED Conferences. https://www.ted. com/talks/ken_robinson_says_schools_kill_creativity

Smith, C. A. (2016). Creativity East and West: Preconceptions and misunderstandings. In P. Clements, A. Krause, \& H. Brown (Eds.), Focus on the learner (pp. 44-50). Japan Association for Language Teaching. Retrieved from https://jalt-publications.org/files/pdf-article/jalt2015pcp_007.pdf
Smith, C. A. (2017). Student-reported creativity and language output: Assessing hypotheses. In P. Clements, A. Krause, \& H. Brown (Eds.), Transformation in language education (pp. 195-202). Japan Association for Language Teaching. Retrieved from https://jalt-publications.org/sites/ default/files/pdf-article/jalt2016-pcp-025.pdf

Smith, C. A. (2018). "Creativity" in Japanese education policy. In P. Clements, A. Krause, \& P. Bennett (Eds.), Language teaching in a global age (pp. 8-14). JALT. Retrieved from https://jaltpublications.org/sites/default/files/pdf-article/jalt2017-pcp-002.pdf

Swann, J., Pope, R., \& Carter, R. (2011) (Eds.). Creativity in language and literature: The state of the art. Palgrave Macmillan. http://dx.doi.org/10.1007/978-1-349-92482-0

Trilling, B., \& Fadel, C. (2009). 21st Century Skills: Learning for life in our times. Jossey-Bass.

UNCTAD. (2019). How the creative economy can help power development. https://unctad.org/news/ how-creative-economy-can-help-power-development

UNDP, \& UNESCO. (2013). Creative economy report 2013 special edition: Widening local development pathways. http://www.unesco.org/culture/pdf/creative-economy-report-2013.pdf 